\title{
PERANAN HUKUM DALAM PENYELESAIAN SENGKETA E COMMERCE
}

\author{
Trinas Dewi Hariyana \\ Fakultas Hukum Universitas Islam Kadiri (UNISKA) \\ Jalan Sersan Suharmaji No.38 Kediri, Jawa Timur, Indonesia
}

\begin{abstract}
E commerce provides convenience in conducting trade. Internet media has no geographical limitation in the transaction does not close the possibility raises several problems in the event of a dispute. Law in that it has an important role to oversee the course of trading through E Commerce. The presence of online arbitration is a breakthrough in the choice of dispute resolution $E$ commerce. Online Arbitration can be an alternative in choosing a dispute resolution for $e$ commerce e commerce cross-border nature. Implementation of online arbitration in Indonesia still has many obstacles both in terms of regulation and network based infrastructure sufficient internet online arbitration proceedings to run smoothly and provide certainty and legal protection.
\end{abstract}

Keywords : E commerce, Dispute Resolution, Legal Protection

\begin{abstract}
ABSTRAK
E commerce memberikan kemudahan dalam melakukan kegiatan perdagangan. Media internet yang tidak memiliki batasan geografis dalam melakukan transaksi tidak menutup kemungkinan menimbulkan beberapa kendala apabila terjadi suatu sengketa. Hukum dalam hal ini memiliki peranan penting untuk mengawal jalannya perdagangan melalui E Commerce. Hadirnya arbitrase online merupakan terobosan dalam pilihan penyelesaian sengketa E commerce. Arbitrase online bisa menjadi alternative dalam memilih penyelesaian sengketa e commerce karena e commerce yang sifatnya lintas batas. Penerapan arbitrase online di Indonesia masih memiliki banyak kendala baik dari segi regulasi maupun infrastrukstur jaringan internet yang memadai agar proses arbitrase secara online bisa berjalan lancar dan memberikan kepastian serta perlindungan hukum
\end{abstract}

Kata Kunci : E Commerce, Penyelesaian Sengketa, Perlindungan Hukum 


\section{A. PENDAHULUAN}

\section{Latar Belakang Masalah}

Kegiatan ekonomi merupakan suatu rangkaian kegiatan yang dilakukan oleh manusia dalam rangka memenuhi kebutuhannya baik kebutuhan primer, sekunder ataupun tersier. Kegiatan ekonomi ini sudah ada sejak awal peradaban hingga saat ini. Perdagangan pun semakin besar dan luas baik pada ragam, volume maupun tujuannya. Pada hakikatnya kegiatan ekonomi dilaksanakan oleh pelaku ekonomi. Pelaku ekonomi itu sendiri bisa berupa perorangan ataupun badan usaha. kegiatan ekonomi itu sendiri dilakukan secara terus menerus, terang-terangan dan orientasinya adalah mencari keuntungan. Kegiatan itu berkembang dan tumbuh dengan banyak variasi yang beragam dalam jumlah dan volume kerja yang relative besar dan terus bertambah sesuai permintaan barang dan jasa dari masyarakat itu sendiri. Jadi pada intinya anggota masayarakat melakukan kegiatan tersebut tidak lain dalam rangka memenui permintaan masyarakat juga.

Berkembangnya kebutuhan dan permintaan masyarakat terhadap barang dan jasa selalu dipenuhi karena beberapa hal salah satunya adalah majunya ilmu pengetahuan dan teknologi sehingga mendorong pertumbuhan industri baik pada ragam, kuantitas maupun percepatan pembaruan. Pertumbuhan industri ini juga akan memacu besarnya lapangan kerja sehingga mendorong meningkatnya kesejahteraan yang selanjutnya juga akan meningkatkan daya beli dan pada akhirnya menyebabkan industry dan perdagangan juga semakin meningkat.

Berkembangnya ilmu pengetahuan dan teknologi informasi juga semakin mendorong kegiatan ekonomi yang pada awalnya hanya berskala nasional menjadi kegiatan ekonomi yang mendunia. Majunya teknologi baru juga akan mendorong berkembangnya teknologi informasi berikut dengan industri yang berkaitan dengan teknologi informasi tersebut. Dan pada suatu tingkatan tertentu, permintaan dan penawaran barang dan jasa dalam masayarakat seperti saling mengejar demi memenuhi permintaan 
dan penawaran. Keadaan dan peristiwa tersebut menunjukkan bahwa kegiatan ekonomi itu memang tumbuh dan berkembang sejalan dengan pertumbuhan dan perkembangan kebutuhan manusia.

Hadirnya teknologi informasi menciptakan suatu dunia yang tanpa batas dan hal ini lah yang akhirnya membawa pengaruh pada system perekonomian yang pada awalnya hanya berupa system konvensional menjadi sutau system yang disebut dengan system online. Internet sebagai salah satu bentuk dari teknologi menghasilkan ruang yang tidak memiliki batasan geografis. Semua orang bisa melakukan aktifitas melalui internet tanpa harus terbatasi oleh ruang dan waktu. Keunggulan internet tersebut membawa dampak pada kegiatan perekonomian manusia. Salah satu kegiatan perekonomian yang terkena dampak dari berkembangnya teknologi adalah mulai berkembanganya system transaksi baik itu pemasaran dan jual beli yang dilakukan melalui media electronic. Transaksi yang demikian in dikenal dengan nama electronic commerce atau e commerce atau yang dalam bahasa Indonesia disebut dengan perdagangan electronic.

Secara umum e commerce dapat didefinisikan sebagai bentuk transaksi perdagangan barang dan jasa melalui media electronic. Transaksi perdagangan melalui internet memang sangat menguntungkan bagi para pihak baik bagi produsen maupun bagi konsumennya. Bagi produsen hadirnya e commerce memudahkan dalam pemasaran produk yang mereka miliki bahkan dengan e commerce mereka bisa memasarkan produk mereka ke seluruh penjuru dunia tanpa harus dibatasi oleh letak geografis. Sedangkan bagi konsumen hadirnya e commerce telah mengubah cara berbelanja konsumen, konsumen diberi kemudahan dalam memperoleh produk tanpa harus dibatasi oleh ruang dan waktu, mereka bisa melakukan transaksi 24 jam.

Keuntungan dan kemudahan yang ditawarkan dalam melakukan transaksi melalui internet menjadikan system perdagangan secara online ini sangat diminati sehingga perdagangan secara online ini semakin 
popular dari tahun ke tahun. Kepopuleran perdangan secara online ini tidak menutup kemungkinan timbul adanya permasalah seperti terjadinya konflik ataupun sengketa antara penjual dan pembeli yang melakukan transaksi melalui internet. Media internet yang hanyalah berupa media electronic memang tidak memiliki batas ruang dan waktu, tetapi ketika suatu transaksi dilakukan melalui internet para pihak yang melakukan transaksi hanya melakukan melalui media internet tanpa bertatap muka satu sama lain, sehingga hal tersebut tidak menutup kemungkinan adanya oknum-oknum yang memanfaatkan system perdagangan ini untuk mengambil keuntungan dengan caracurang yang pada akhirnya merugikan konsumen seperti tindakan-tindakan criminal dalam transaksi, maupun pelanggaran-pelanggaran di luar pengawasan.

Kemunkinan munculnya permasalahan dalam transaksi e commerce menimbulakn beberapa permasalahan dalam melakukan penyelesaiannya. Media internet yang tidak memiliki batasan geografis dalam melakukan transaksi menimbulkan beberapa kendala dalam melakukan penyelesaian sengketa apabila terjadi suatu sengketa, seperti masalah jauhnya jarak antara para pihak, perbedaan Negara para pihak yang melakukan perdagangan juga mengakibatkan masalah dengan adanya perbedaan bahasa, budaya bahkan hukum yang berlaku di masing-masing negara, sehingga menyulitkan dalam penentuan hukum yang digunakan dalam menyelesaikan suatu sengketa e commerce.

\section{Rumusan Masalah}

a. Upaya apakah yang dapat dilakukan dalam menyelesaikan sengketa e commerce.

b. Apakah upaya penyelesaian secara non litigasi dapat menjadi suatu pilihan penyelesaian yang utama dalam menyelesaikan sengketa e commerce yang memiliki sifat lintas batas. 


\section{Tujuan Penelitian}

a. Mengetahui upaya apakah yang dapat dilakukan dalam menyelesaikan sengketa e commerce

b. Menelaah secara mendalam upaya penyelesaian secara non litigasi dapat menjadi suatu pilihan penyelesaian yang utama dalam menyelesaikan sengketa e commerce yang memiliki sifat lintas batas.

\section{B. PEMBAHASAN}

\section{Upaya Penyelesaian Sengketa E Commerce}

Hadirnya teknologi informasi saat ini telah memberikan perubahan yang sangat besar bagi tata cara kehidupan masayarakat. Melalui teknologi semua system atau cara menjadi lebih mudah, cepat dan efisien. Perkembangan teknologi informasi ini membawa dampak yang cukup besar dalam setiap aspek kehidupan masyarakat termasuk dalam aspek perekonomian. Technology telah mendorong berkembangnya system perekonomian termasuk di dalamnya adalah kegiatan perindustrian dan perdagangan.

Internet sebagai suatu media informasi dan komunikasi elektronik telah banyak dimanfaatkan untuk berbagai kegiatan, antara lain untuk menjelajah (browsing, surfing), mencari data dan berita, saling mengirim pesan melalui email, dan perdagangan. Kegiatan perdagangan dengan memanfaatkan media internet ini dikenal dengan istilah electronic commerce, atau disingkat e-commerce. ${ }^{47} \mathrm{E}$ Commerce atau electronic commerce atau dalam bahasa Indonesia disebut perdagangan elektronik adalah penyebaran, pembelian, penjualan, pemasaran barang dan jasa melalui sistem elektronik seperti internet atau televisi, www, atau jaringan komputer lainnya. E-dagang dapat melibatkan transfer dana elektronik,

47 Ahmad. M. Ramli, Cyber Law dan Haki Dalam Sistem Hukum Indonesia, Bandung: Refika Aditama,2004, hlm. 1 
pertukaran data elektronik, sistem manajemen inventori otomatis, dan sistem pengumpulan data otomatis. ${ }^{48}$

E commerce pada dasarnya sama dengan jual beli konvensional, yang menjadi perbedaan hanyalah media yang digunakan. Pengertian jual beli smenurut Prof. Subekti, adalah suatu perjanjian dengan perjanjian itu pihak yang satu mengikatkan dirinya untuk menyerahkan hak milik atas suatu barang dan pihak yang lain untuk membayar harga yang telah dijanjikan. ${ }^{49}$ Dari definisi tersebut maka dapat diuraikan unsur-unsur dari jual beli adalah:

a. Adanya subjek hukum yaitu penjual dan pembeli

b. Adanya kesepakatan antara penjual dan pembeli tentang harga dan barang

c. Adanya hak dan kewajiban yang timbul antara pihak penjual dan pembeli.

Dalam e commerce juga ada dua pelaku atau subyek hukum yaitu merchant yang melakukan penjualan dan customer atau buyer yang berperan sebagai pembeli. Proses pelaksanaan jual beli melalui internet atau e commerce juga sama dengan proses pelaksanaan perdagangan pada umumnya, yaitu:

a. Adanya penawaran, yaitu penawaran yang dilakukan oleh penjual atau pelaku usaha melalui situs internet. Pelaku usaha membuat suatu catalog yang berisi produk-produk berikut keterangan baik harga dan deskripsi dari produk itu sendiri sehingga customer bisa dengan leluasa memilih produk dan melakukan penawaran dengan pelaku usaha.

b. Adanya penerimaan, yaitu jika seseorang berminat untuk membeli barang yang ditawarkan maka customer dapat melakukan kesepakatan dengan penjual atau pelaku usaha, dan pelaku usaha akan menyimbang barang yang sudah

${ }^{48}$ http://id.wikipedia.org/wiki/Perdagangan elektronik

${ }^{49}$ Subekti, Hukum Perjanjian, Jakarta: Intermasa, 1985, hlm. 79 
dipilih dan disepakati oleh customer hingga customer selesai melakukan pembayaran terhadap barang tersebut.

c. Adanya pembayaran, yaitu sutu proses setelah terjadi kesepakatan jual beli antara pembeli dan penjual. Dalam melakukan pembayaran biasanya dilakukan dengan cara transfer melalui ATM karena dinilai lebih mudah dan lebih cepat

d. Adanya pengiriman, yaitu suatu proses dimana setelah pembeli melakukan pembayaran atas barang yang telah disepakati maka penjual wajib mengirimkan barang tersebut karena barang tersebut sudah beralih hak kepemilikannya sejak pembeli sudah melakukan pembayaran atas barang tersebut. Dalam mengirimkan barang ke pembeli,penjual biasanya bekerjasama dengan pengusaha jasa pengiriman barang.

Jadi jika dalam jual beli konvensional kesepakatan dilakukan secara langsung dan terjadi tatap muka antara penjual dan pembeli, sedangkan jika dalam e commerce yang dipergunakan adalah media elektronik atau internet sehingga kesepakatan atau perjanjian yang tercipta adalah melalui dunia maya atau online. Secara umum transaksi e commerce dapat dikelompokkan menjadi dua yaitu:

a. Business to business, adalah transaksi antar perusahaan (baik pembeli maupun penjual adalah perusahaan). Biasanya di antar mereka telah saling mengetahui satu sama lain dan sudah terjalin hubungan yang cukup lama. Pertukaran informasi hanya berlangsung di antara mereka dan pertukaran informasi itu di dasarkan pada kebutuhan dan kepercayaan. Perkembangan business to business lebih pesat jika dibandingkan dengan perkembangan jenis e commere yang lainnya. 
b. Business to customer, adalah transaksi antara perusahaan dengan konsumen/individu, contohnya amazon.com sebuah situs e commerce yang besar dan terkenal. Pada jenis ini, tansaksi disebarkan secara umum dan konsumen yang berinisiatif melakukan transaksi. Produsen harus siap menerima respon dari konsumen tersebut. Biasanya system yang digunakan adalah system web karena system ini yang sudah umum dipakai dikalangan masayarakat.

Sistem perdagangan dengan memanfaatkan sarana internet memberi keuntungan tersendiri bagi masyarakat baik bagi penjual maupun bagi pembelinya. Penggunaan internet sebagai sarana perdagangan memberikan banyak kemudahan dan disamping kemudahan yang ditawarkan, banyak hal yang mungkin terjadi dalam perdangangan. Perdangangan melalui internet memang memberikan banyak keuntungan tetapi tidak menutup kemungkinan juga menimbulkan masalah dari transaksi online tersebut.

Menurut penelitian yang dilakukan oleh sebuah lembaga internasional, telah banyak kasus yang merugikan konsumen sebagai akibat dari penggunaan media internet dalam transaksi perdagangan. Satu dari setiap sepuluh kasus pengiriman barang dapat dipastikan terlambat atau tidak sampai kepada konsumen, ada juga yang menerima barang tidak sesuai dengan pemesanan bahkan sampai barangnya tidak dikirim. Selain itu banyak juga penjual (suppliers atau sellers) yang tidak mampu memberikan kwitansi atau bukti transaksi dan sebagainya. ${ }^{50}$ Oleh karena itu dalam hal ini peranan hokum diperlukan guna menyelesaikan permasalahan- permasalahan tersebut sehingga kepercayaan masyarakat dalam menggunakan transaksi perdagangan melalui media internet tetap terjaga dan tidak

${ }^{50}$ Dikdik Arief Mansur dan Elisatris Gultom, Cyber Law (Aspek Hukum Technology Informasi), Bandung : Refika Aditama, 2005, hlm. 167 
memudar karena adanya jaminan dan kepastian hokum akan penyelesaian sengketa-sengketa tersebut.

Sifat e commerce yang menggunakan media elektronik sebagai media penghubung para pihak dalam melakukan perdagangan membuat e commerce tidak hanya berskala nasioanl saja tetapi juga internasional karena tidak terbatasnya dunia internet membuat perdagangan yang dilakukan juga tidak terbatas oleh kondisi geografis sehingga perdagangannya bisa dilakukan oleh para pihak dari berbagai belahan dunia. Jika dalam e commerce terjadi sengketa yang melibatkan para pihak yang tinggal di satu negara maka dalam penentuan hokum guna menyelesaikan sengketa tidaklah sulit. Jika sengketa tersebut melibatkan para pihak yang merupakan warga negara Indonesia maka, maka dalam menyelesaikannya dapat menggunakan hukum yang ada di Indonesia. Saat ini Indonesia sudah memiliki beberapa perangkat hokum yang bisa digunakan untuk menjadi acuan dalam menyelesaikan sengketa e commerce.

Lahirnya undang-undang nomor 11 tahun 2008 tentang informasi dan transaksi electronic adalah salah satu bentuk upaya pemerintah guna melindungi para pihak yang melakukan transaksi melalui media electronic. Beberapa pasal dalam Undang-Undang Internet dan Transaksi Elektronik yang berperan dalam e-commerce adalah sebagai berikut Pasal 2, 9, 10, 18, 20, 21, 22, 30, dan pasal 46. Selain mengacu kepada Undang-Undang Nomor 11 Tahun 2008 Tentang Internet \& Transaksi Elektronika di atas, ada beberapa peraturan atau perundangan yang mengikat dan dapat dijadikan sebagai payung hukum dalam kegiatan bisnis e-commerce, diantaranya adalah :
a. Kitab Undang-Undang Hukum Pidana
b. Kitab Undang-Undang Hukum Acara Pidana
c. Kitab Undang-Undang Hukum Perdata
d. Kitab Undang-Undang Hukum Acara Perdata 
e. Kitab Undang-Undang Hukum Dagang

f. Undang-Undang Nomor 8 Tahun 1997 Tentang Dokumen Perusahaan

g. Undang-Undang Nomor 30 Tahun 2000 Tentang Rahasia Dagang

h. Undang-Undang Nomor 40 Tahun 2007 Tentang Perseroan Terbatas

i. Undang-Undang Nomor 36 tahun 1999 Tentang Telekomunikasi

j. Undang-Undang Nomor 5 Tahun 1999 Tentang Larangan Praktik Monopoli dan Persaingan Usaha Tidak Sehat.

k. Undang-Undang Nomor 8 Tahun 1999 Tentang Perlindungan Konsumen. ${ }^{51}$

Namun demikian, bila para pihak yang terlibat sengketa e commerce berada di luar yuridiksi hukum Indonesia, maka persoalan pilihan hukum ini tergantung dari perjanjian antara pihak penjual dan pembeli (dengan cara menyantumkannya dalam salah satu klausul di perjanjian e-commerce). Kesulitan-kesulitan yang timbul apabila terjadi sengketa antara para pihak di dalam transaksi $e$ commerce, bukan saja menyangkut pilihan hukum yang akan diterapkan untuk dijadikan dasar menyelesaikan sengketa yang timbul, tetapi juga mengenai pilihan pengadilan yang akan memeriksa sengketa tersebut. Hal itu dapat dihindari apabila para pihak menentukan di dalam perjanjian di antara mereka pengadilan mana yang mereka pilih untuk menyelesaikan sengketa yang mungkin timbul di kelak kemudian hari berkenaan dengan pelaksanaan dan penafsiran perjanjian di antara mereka.

Choice of law ini merupakan bagian dari kebebasan berkontrak, yaitu para pihak bebas untuk menentukan isi dari

${ }^{51}$ Sekilas Kejahatan E-COMMERCE Di Indonesia « Makalah, Berita, Paparan dan Diskusi Masalah Hukum 'Law Education'.htm 
kontrak, termasuk pilihan hukumnya. Asas kebebasan berkontrak ini di Indonesia dianut dalam pasal 1338 Kitab Undang-Undang Hukum Perdata, yaitu:

"Semua persetujuan yang dibuat sesuai dengan undang-undang berlaku sebagai undang-undang bagi mereka yang membuatnya. Persetujuan itu tidak dapat ditarik kembali selain dengan kesepakatan kedua belah pihak, atau karena alasanalasan yang ditentukan oleh undang-undang”

Hal di atas juga diperkuat dalam pasal 18 ayat (1) dan ayat (2) Undang-Undang No. 11 Tahun 2008 tentang Informasi dan Transaksi Elektronik:

"Transaksi Elektronik yang dituangkan ke dalam Kontrak Elektronik mengikat para pihak"

"Para pihak memiliki kewenangan untuk memilih hukum yang berlaku bagi Transaksi Elektronik internasional yang dibuatnya"

Jelasnya, berdasarkan hal-hal di atas pemilik situs internet bebas atau diperbolehkan untuk mencantumkan persyaratan dan ketentuan (terms and conditions) tertentu, termasuk pemilihan hukum yang berlaku bagi transaksi elektronik yang diselenggarakan oleh situs yang bersangkutan. Syarat dan ketentuan dalam situs internet pada umumnya dituangkan dalam bentuk perjanjian atau klausula baku di mana konsumen tinggal mengklik tombol-tombol tertentu sebagai tanda persetujuan atas apa yang disyaratkan si penjual dalam situs bersangkutan. Klausula baku seperti ini ditujukan untuk mempermudah terjadinya transaksi, karena akan menyulitkan apabila si penjual harus membuat dan menegosiasikan kontrak baru untuk setiap transaksi yang terjadi. Oleh karena itu, sebaiknya calon pembeli membaca dengan seksama isi terms and conditions sebelum mengklik tombol yang menyatakan persetujuannya. $^{52}$

\footnotetext{
${ }^{52}$ http://hukumonline.com/klinik/detail/cl1467
} 
Para pihak dapat pula menentukan di dalam perjanjian itu bahwa sengketa yang mungkin timbul di kelak kemudian hari diselesaikan oleh suatu badan arbitrase, baik badan arbitrase institusional maupun badan arbitrase ad hoc. Klausul dalam perjanjian yang mengatur mengenai hal ini disebut arbitration provisions atau klausul arbitrase. Dalam hal tidak dicantumkannya pilihan hukum dalam perjanjian e-commerce nya, ada beberapa teori yang berkembang untuk menentukan hukum mana yang digunakan/berlaku, diantaranya:

a. Mail box theory (Teori Kotak Pos)

Dalam hal transaksi e-commerce, maka hukum yang berlaku adalah hukum di mana pembeli mengirimkan pesanan melalui komputernya. Untuk ini diperlukan konfirmasi dari penjual. Jadi perjanjian atau kontrak terjadi pada saat jawaban yang berisikan penerimaan tawaran tersebut dimasukkan ke dalam kotak pos (mail box).

b. Acceptance theory (Teori Penerimaan)

Hukum yang berlaku adalah hukum di mana pesan dari pihak yang menerima tawaran tersebut disampaikan. Jadi hukumnya si penjual.

c. Proper Law of Contract

Hukum yang berlaku adalah hukum yang paling sering dipergunakan pada saat pembuatan perjanjian. Misalnya, bahasa yang dipakai adalah bahasa Indonesia, kemudian mata uang yang dipakai dalam transaksinya Rupiah, dan arbitrase yang dipakai menggunakan BANI, maka yang menjadi pilihan hukumnya adalah hukum Indonesia.

d. The most characteristic connection 
Hukum yang dipakai adalah hukum pihak yang paling banyak melakukan prestasi. $^{53}$

Dengan adanya kebebasan para pihak dalam menentukan hokum yang dipilih maka akan tercipta suatu kejelasan dan kepastian hokum bagi para pihak yang melakukan kegiatan e commerce sehingga mereka juga merasa aman dan terjamin dalam melakukan bisnis melalui e commerce karena mereka sudah mendapat kepastian hukum jika suatu saat terjedi sengketa dalam bisnis e commerce yang mereka lakukan.

\section{Prospek Penyelesaian Sengketa E Commerce Dengan Cara Non Litigasi}

Suatu sengketa biasanya timbul karena adanya wanprestasi yang dilakukan oleh salah satu pihak sehingga menimbulkan kerugian di pihak yang lain. Dalam e commerce penyelesaian sengketa dapat dilakukan melalui pengadilan dapat pua dilakukan melalui arbitrase yang memiliki kekuatan hokum yang sama, juga ADR ( Alternative Dispute Resolution) yang memiliki kekuatan sebagai akta van compromise. ${ }^{54}$

Penyelesaian sengketa melalui jalur litigasi atau pengadilan dapat menggunakan hokum acara pidana ataupun hokum acara perdata dengan dasar hokum bisa mengunakan kitab undang-undang hokum pidana, atau kitab undang-undang hokum perdata, atau menggunakan undang-undang yang lebih khusus lagi seperti undang-undang tentang Informasi dan Transaksi electronic atau Undang-undang tentang Perlindungan Konsumen, tergantung dari sengketa apa yang dialami. Ketiadaan ketentuan khusus yang mengatur tentang $\mathrm{E}$ commerce tidak boleh menjadi alasan penolakan pemeriksaan dan pengadilan suatu perkara. Hal in tercantum dalam pasal 16 Undang-undang No. 4 Tahun 2004 tentang Kekuasaan Kehakimana sebagaimana telah diubah dengan UndangUndang No. 48 Tahun 2009 Pasal 10. Dalam hal in hakim wajib

${ }^{53}$ http://hukumonline.com/klinik/detail/cl5517

${ }^{54}$ Ahmad. M. Ramli,hal 91 
menggali, mengikuti dan memahami nilai-nilai hukum dan rasa keadilan yang hidupdalam masyarakat termasuk eksistensi alat bukti electronic.

Suatu transaksi electronic tidak memerlukan hard copy atau warkat kertas, namun demikian setiap transkasi yang melibatkan eksekusi diberikan tanda bukti berupa nomer atau kode yang dapat disimpan atau direkam di computer atau dicetak. Dalam undang-undang ITE telah diatur bahwa tanda tangan electronic dan dokumen electronic dapat dijadikan sebagai alat bukti. Pengakuan catatan transaksi electronic sebagai alat bukti yang sah di pengadilan sudah dirintis oleh United Nation Commision on International Trade (UNCITRAL) yang mencantumkan dalam E commerce model law ketentuan mengenai transaksi elektroik diakui sederajat dengan tulisan di atas kertas sehingga tidak dapat ditolak sebagai bukti pengadilan. ${ }^{55}$ Selanjutnya untuk beban pembuktian yang terkait dengan teknologi informasi sudah selayaknya dibebankan kepada pemilik teknologi tinggi bukan kepada konsumen ${ }^{56}$

Proses penyelesaian sengketa yang ditempuh melalui jalur pengadilan atau litigasi ini memiliki banya kelemahan, seperti:

a. Litigasi memaksa para pihak berada pada posisi yang ekstrim dan memerlukan pembelaan (advocacy).

b. Litigasi mengangkat seluruh persoalan dalam suatu perkara, sehingga mendorong para pihak untuk melakukan penyelidikan terhadap kelemahan-kelemahan pihak lainnya.

c. Proses litigasi memakan waktu yang lama dan memakan biaya yang mahal.

d. Hakim seringkali bertindak tidak netral dan kurang mengikuti perkembangan ilmu pengetahuan yang mendasari penyelesaian suatu hukum baru.

Berdasarkan berbagai kelemahan di atas nampak jelas bahwa penyelesaian melalui jalur pengadilan atau litigasi tidak sesuai

${ }^{55}$ Dikdik Arief Mansur, et al, hlm. 110

${ }^{56}$ Ahmad. M. Ramli, ,hlm. 33 
dengan hakikat dari e commerce yang bersifat virtual atau maya dan membutuhkan suatu system yang efektif, efisien dan murah. ${ }^{57}$

Kendala yang sering dihadapi dalam menyelesaikan sengketa e commerce adalah sifat e commerce yang lintas batas memungkinkan para pihak yang terlibat di dalamnya tidak berada dalam satu negara sehingga jika penyelesaian sengketa menggunakan jalur litigasi dimana para pihak di wajibkan hadir dalam persidangan maka hal itu tentu saja menyulitkan apabila para pihak berada dalam negara yang berbeda. Selain itu perbedaan negara juga tentunya mengakibatkan perbedaan keberlakuan hokum sehingga akan menyulitkan dalam menentukan hokum yang akan diberlakukan dalam menyelesaikan sengketa. Oleh karena itu diperlukan suatu upaya penyelesaian alternative di liauar jalur litigasi yang lebih efektif, mudah dan efisien dalam menyelesaikan sengketa.

Salah satu upaya penyelesaian tersebut adalah dengan mengunakan arbitrase. Dalam Undang-undang No 11 Tahun 2008 tentang ITE juga di atur tentang pilihan penyelesaian sengketa dengan menggunakan arbitrase, hal itu dijelaskan dalam pasal 39 Ayat (2) yaitu:

"Selain penyelesaian gugatan perdata sebagaimana dimaksud pada Ayat (1). Para pihak dapat menyelesaikan sengketa melalui arbitrase atau lembaga penyelesaian sengketa alternative lainnya sesuai dengan ketentuan perundangundangan."

Hal tersebut tentunya bisa menjadi alternative dalam memilih penyelesaian sengketa e commerce apalagi jika sengketa itu melibatkan para pihak yang berada dalam wilayah hukum yang berbeda. Dipilihnya mekanisme penyelesaian sengketa alternative sebagai salah satu cara penyelesaian sengketa e commerce dikarenakan beberpa factor yaitu : murah, cepat, dapat menjaga

\footnotetext{
${ }^{57}$ Dikdik Arief Mansur,et al, hlm. 168
} 
hubungan baik para pihak yang bersengketa, terjaga kerahasiaannya, penyelesaian dilakukan oleh para ahli di bidangnya serta tidak berpihak atau netral

Arbitrase diatur dalam Undang-undang Nomor 30 Tahun 1999 tentang Arbitrase. Dalam undang-undang tersebut terdapat pengertian arbitrase yang diatur dalam Pasal 1 Ayat (1) yaitu:

“Arbitrase adalah cara penyelesaian suatu sengketa perdata diluar peradilan umum yang didasarkan pada perjanjian arbitrase yang dibuat secara tertulis oleh pihak yang bersengketa"

Perjanjian arbitrase merupakan perjanjian pelengkap atau tambahan atau accesoir yang sering dilekatkan dalam persetujuan bisnis atau persetujuan komersial. Perjanjian komersial yang bercorak transnasional atau internasional hampir selalu dibarengi dengan perjanjian arbitrase. Sedang perjanjian komersial yang berskala nasional, dimana para pihak terdiri dari kalangan orang Indonesia sendiri, belum seluruhnya dibarengi dengan persetujuan arbitrase. $^{58}$

Menurut Yahya Harahap sengketa yang harus diselesaikan (melalui arbitrase) pada umumnya bersumber dari sengketa atas sebuah kontrak yang disebabkan:

Perbedaan penafsiran (dispute) mengenai pelaksanaan perjanjian, berupa:
a. Kontraversi pendapat (controversy)
b. Kesalahan pengertian (misunderstanding)
c. Ketidaksepakatan (disagreement)
d. Pelanggaran perjanjian (breach of contract), termasuk di dalamnya:
e. Berlaku atau tidaknya kontrak
f. Pengakhiran kontak (termination of contract)

${ }^{58}$ Yahya Harahap, Arbitrase, Jakarta: Sinar Grafika, 2006, hlm. 23 
g. Klaim mengenai ganti rugi atas wnprestasi atau perbuatan melawan hukum. ${ }^{59}$

Dalam sengketa e commerce yang melibatkan 2 wilayah hokum negara yang berbeda landasan arbitrase yang digunakan adalah UNCITRAL Arbitration Rules. Sumber hokum arbitrase in sudah dimasukkan ke dalam system hokum nasional Indonesia. United Nations Commision on International Trade Law (UNCITRAL) adalah suatu komisi di bawah naungan PBB. UNCITRAL telah membuat suatu panduan dan pegangan untuk melakukan transaksi bisnis secara e-commerce dan hal-hal lainnya dengan nama UNCITRAL Model Law on Electronic Commerce, dan telah telah disetujui berdasarkan General Assembly Resolution No. 51/162 tanggal 16 Desember 1996. UNCITRAL Model itu telah menjadi dasar pembuatan undang-undang e-commerce atau cyber law dari banyak negara, antara lain Electronic Transaction Act of Singapore dan undang-undang sejenis dari Malaysia. ${ }^{60}$

Putusan arbitrase versi UNCITRAL in bersifat final dan binding, artinya putusan tersebut langsung menjadi putusan tingkat pertama dan terkahir. Putusan langsung mengikat (binding) kepada para pihak. terhadap putusan. Tertutup upaya hokum banding dan kasasi. Melekatnya sifat final dan binding dalam putusan arbitrase, terhitung sejak salinan putusan (copy of the award) di sampaikan mahkamah arbitrase kepada para pihak dan sejak tanggal penerimaan salinan putusan, putusan langsung final dan mengikat pada para pihak dan jika salah satu pihak tidak mau mmenuhi pelaksanaan putusan arbitrase secara sukarela, pemenuhan dapat dipaksa melalui ekseskusi oleh pengadilan dengan jalan mengajukan permohonan untuk itu sesuai dengan ketentuan ekseskusi yang berlaku terhadap putusan pengadilan.

\footnotetext{
${ }^{59}$ Dikdik Arief Mansur, et al, hlm. 178

${ }^{60} \mathrm{http}: / /$ hukumonline.com/klinik/detail/cl5397
} 
Cara penyelesaian melalui arbitrase merupakan salah satu dari alternative penyelesaian sengketa yang memberikan banyak keuntungan tetapi juga memiliki kelemahan karena dalam prakteknya penyelesaian sengketa melalui arbitrase selain memakan waktu lama juga biaya yang mahal. Arbitrase secara tradisional ini juga tidak cukup membantu dalam upaya penyelesaian sengketa e commerce, karena sifat e commerce yang cyberspace sehingga hanya menimbulkan masalah baru. Para pihak yang terlibat dalam e commerce lebih banyak bertemu melalui media internet karena secara fisik mereka tinggal di tempat yang jauh satu sama lain bahkan tidak menutup kemungkinan mereka tinggal di Negara yang berbeda. Sedangkan pilihan penyelesaian sengketa melalui litigasi maupun arbitrase tradisional memaksa para pihak untuk, hal tersebut tentu saja memberikan kesulitan baru bagi para pihak dalam melakukan penyelesaian sengketa.

Oleh karena itu diperlukan suatu cara penyelesaian sengketa yang sesuai dengan sifat karakteristik e commerce dan juga memberikan kepastian hokum sehingga tercapai suatu penyelesaian yang cepat, murah, dan efektif. Sistem penyelesaian sengketa dalam e-commerce yang mengutamakan efesiensi, efektifitas dan biaya murah saat ini dapat diselesaikan dengan alternatif penyelesaian sengketa yang mempunyai kesamaan system dengan arbitrase tradisional, yaitu arbitrase online. Di beberapa negara maju arbitrase online sudah lama dikenal dan sudah terbiasa menyelesaikan sengketa. Lembaga yang menawarkan ADR online antara lain eResolutions.com,Online Mediators, Virtual Magistrate, American Arbitration association dan sebagainya.

Pengertian arbitarse on-line sendiri adalah cara penyelesaian sengketa secara arbitrase dengan menggunakan alat elektronik/digital dalam penyelenggaraannya. Jadi pada dasarnya arbitrase online adalah sama dengan arbitrase tradisional, hanya saja 
yang membedakan adalah media internet yang digunakan sebagai penghubung antara para pihak untuk bertemu dan menyelesaikan sengketa. The virtual magistrate adalah pelopor hadirnya arbitrase online yang diciptakan oleh para akademisi hokum dunia maya yang bekerja untuk National Center For Automated Information Research (NCAIR) yang diciptakan pada tahun 1995. Di tahun yang sama Asosiasi Arbitrase America juga menciptakan Cyberspace IMW Institute.

Adapun prosedur penyelenggaraan arbitrase online adalah sebagai berikut : ${ }^{61}$

Peraturan yang diperlukan mengenai permohonan untuk berarbitrase dan pelaksanaannya (hal ini meliputi peraturan yang diterapkan oleh badan arbitrase mengenai informasi yang disediakan oleh salah satu fihak menyangkut adanya sengketa, pada sengketa konsumen hal ini berarti penyediaan formulir complain secara online, dan pada sengketa business to business tersedianya formulir online berisi permintaan untuk melakukan arbitrase termasuk peraturan penyediaan perjanjian arbitrase) :

a. Menyediakan cara memilih arbitrator, menerima tempat kedudukan atau menolaknya;

b. Menyediakan tata cara berarbitrase seperti penyediaan peraturan prosedural seperti tata cara mengajukan perkara secara online, menyampaikan tanggapan, mengajukan bukti-bukti, argumentasi dan kemungkinan-kemungkinan adanya penundaan;

c. Penyediaan tata cara penggunaan pesan-pesan secara elektronik, seperti penyelenggaraan prosedur yang hanya menggunakan dokumen elektronik, penggunaan video conferencing dan audio conferencing termasuk dalam hal

${ }^{61}$ Faizin Sulistio " Tinjauan Yuridis arbitrase Online sebagai alternatif Penyelesaian sengketa E-Commerce" 
ini adalah penyediaan alat-alat bukti berupa keterangan saksi dan saksi ahli;

d. Penyediaan pemmbuatan putusan secara online dan persyaratan yang diperlukan agar suatu putusan dapat diterima dan dijalankan;

e. penyediaan prosedur yang mungkin untuk mengadakan perlawanan atau banding terhadap putusan;

f. Penyediaan sarana untuk penyimpanan data terutama dalam perlawanan menyangkut dari salah satu pihak untuk melakukan perlawanan karena adanya dugaan bahwa hak-hak dari salah satu pihak telah dilanggar;

g. Penyediaan prosedur yang memungkinkan proses berjalan secara rahasia dengan menyediakan teknologi enkripsi dan tanda tangan elektronik

Dalam Hukum internasional konstruksi keabsahan dan prosedur dari sebuah perjanjian arbitrase diatur oleh beberapa aturan hukum. Diantara aturan tersebut yang paling berpengaruh dan banyak diikuti dalam menyelesaikan sengketa melalui arbitrase adalah :

a. Perjanjian Arbitrase On line menurut Konvensi New York

Menurut konvensi New York ada tiga hal yang menjadi persyaratan keabsahan sebuah perjanjian arbitrase seperti diatur dalam article II (2) yaitu : tertulis, di tanda tangani dan asli. Secara lengkap bunyi article II (2) adalah :

The term "agreement in writing" shall include an arbitral clause in a contract or arbitration agreement, signed by the parties or contained in an exchange of letter or telegrams.

Dengan interpretasi ektensif mengenai istilah tertulis yang diartikan dapat dibaca dan dimengerti 
maksud dari tulisan tersebut oleh para pihak serta dibuat dalam media tertentu. Maka sinyal-sinyal elektronik yang membentuk suatu huruf, angka yang mempunyai arti dan maksud tertentu yang dapat dipahami oleh para pihak dapat dikatakan sebagai bentuk tertulis.

b. Perjanjian Arbitrase On line Menurut UNCITRAL Model Law

Pendekatan yang diambil dalam model law ini adalah bahwa suatu informasi tidak dapat dikatakan tidak mempunyai kekuatan hukum, hanya karena informasi itu berbentuk data message. Pendekatan ini menganut pemikiran sosiologis jurisprudence yang menggunakan pendekatan pada kebutuhan dan realita praktek hukum yang terjadi dalam masyarakat tentang interpretasi "tertulis" dari aturan teks perundangundangan yang disamakan dengan data message dalam internet. Interpretasi ini akan menimbulkan suatu kepastian dikemudian hari apabila terdapat suatu bentuk/format data messages dalam bentuk yang baru. Pendekatan ini juga akan menyebabkan suatu kontrak/perjanjian yang dibuat dengan digital signature mempunyai kekuatan hukum. Sedangkan apabila dalam suatu perundang-undangan terdapat persyaratan bahwa harus dalam bentuk tertulis, maka persyaratan ini dapat dicapai, selama informasi/data tersebut dapat dilihat/diakses.

Suatu data messages dapat ditandatangani secara elektronis. Ketentuan-ketentuan yang terdapat dalam UNCITRAL model law on E-Commerce adalah sebagai berikut :

a. Segala informasi elektronik dalam bentuk data elektronik dapat dikatakan untuk memiliki akibat 
hukum, keabsahan ataupun kekuatan hukum. (Information shall not be denied legal effect,validity or enforce ability solely on the grounds that it is in the form of a data message).

b. Dalam hal hukum mengharuskan adanya suatu informasi harus dalam bentuk tertulis dikatakan di dalam article 6 UNCITRAL Model Law. "Where the law requires information to be in writing, the requirement is met by a data message if the information contained therein is accessible so as to be useable for subsequent reference.

c. Dalam hal tanda tangan, maka suatu tanda tangan elektronik merupakan tanda tangan yang sah.

d. Dalam hal kekuatan pembuktian dari data yang bersangkutan, maka data message memiliki kekuatan pembuktian.

Suatu penawaran dan penerimaan tawaran tersebut (offer and acceptance) dapat dinyatakan dalam bentuk data message, dan jika data tersebut digunakan sebagai format dari kontrak, maka kontrak tersebut tidak dapat ditolak keabsahan dan kekuatan hukumnya dalam mana data tersebut digunakan, dan dalam hal pihak-pihak yang melakukan offer and acceptance dikatakan sebagai originator, yaitu sebagai pihak yang melakukan suatu pengiriman data dan pihak yang menerima data dikatakan sebagai addressee. $^{62}$

Hadirnya arbitrase online sebagai solusi dalam system penyelesaian sengketa e commerce cuku popular di beberapa Negara maju. Di Negara Indonesia sendiri arbitrase online saat ini masih menjadi perdebatan di antara para ahli hokum. Hal itu karena undang-undang yang mengatur tentang arbitrase saat ini masih menggunakan cara-cara konvensional 
sedangkan cara-cara arbitrase yang demikina cukup sulit diterapkan dalam sengketa e commerce yang bersifat lintas batas.

Pada dasarnya undang-undang arbitrase yang ada saat ini beberapa pasalnya membuka peluang untuk diterapkan arbitrase online di Indonesia salah satunya Pasal 4 ayat (3) Undang-Undang Nomor 30 Tahun 1999 yang berbunyi :

"Dalam hal disepakati penyelesaian sengketa melalui arbitrase terjadi dalam bentuk pertukaran surat, maka pengiriman teleks, telegram, faksimili, e-mail, atau dalam bentuk sarana komunikasi lainnya, wajib disertai dengan suatu catatan penerimaan oleh para pihak".

Berdasarkan ketentuan di atas, dapat dilihat bahwa penyelenggaraan arbitrase online dimungkinkan apabila ada kesepakatan terlebih dahulu dari para pihak untuk menyelenggarakan arbitrase secara online. Untuk klausula tertulis perjanjian arbitrase terdapat dalam Pasal 1 angka 3 dinyatakan :

"Perjanjian arbitrase adalah suatu kesepakatan berupa klausula arbitrase yang tercantum dalam suatu perjanjian tertulis yang dibuat para pihak sebelum timbul sengketa, atau suatu perjanjian arbitrase tersendiri yang dibuat para pihak setelah timbul sengketa ".

Pengertian yang dipaparkan di atas undang - undang tidak memberikan batasan tentang bentuk apa yang harus digunakan yaitu harus tercetak atau tidak, hanya memberikan batasan bahwa perjanjian tersebut secara tertulis. Undang-undang di atas tidak mengatur bahan atau media apa yang digunakan untuk menulis. Penyelesaian sengketa melalui arbitrase konvensional mendasarkan kegiatannya pada pertukaran dan pemeriksaan dokumen bermedia kertas. Sedangkan dalam arbitrase online, media kertas telah tergantikan oleh data digital sehingga tidak diperlukan adanya dokumen berbentuk kertas. Masyarakat sering memahami bahwa suatu dokumen yang asli adalah dokumen yang tertulis di atas kertas, padahal untuk suatu sistem dokumentasi yang menggunakan komputer, dokumen yang asli sebenarnya adalah dalam 
bentuk data elektronik (softcopy) yang tersimpan dalam hardisk komputer bukan dalam bentuk cetaknya (hardcopy). Dengan demikian, nilai dari suatu perjanjian secara substansial tidak bergantung pada media apa yang digunakan melainkan tergantung pada proses terjadinya perjanjian itu sendiri. contohnya, suatu perjanjian arbitrase yang tertulis di atas kertas pun kalau proses penyusunannya tidak memenuhi syarat sah perjanjian maka batal demi hukum. ${ }^{63}$

Dalam hal putusan yang dihasilkan oleh arbitrase online bentuk putusan arbitrase online berbeda dengan bentuk putusan secara tradisional karena putusan dalam arbitrase online dibuat melalui media elektronik dalam bentuk digital, namun dalam ketetentuan yang mengatur mengenai putusan arbitrase tradisional juga berlaku bagi putusan online. Dan hal itu menjadi permasalahan jika arbitrase online diterapkan di Indonesia, hal itu berkaitan dengan UUITE dalam Pasal 5 Ayat (1) dan (4) yang menyatakan bahwa :

(1). Informasi Elektronik dan/atau Dokumen Elektronik dan/atau hasil cetaknya merupakan alat bukti hukum yang sah.

(4). Ketentuan mengenai Informasi Elektronik dan/atau Dokumen Elektronik sebagaimana dimaksud pada ayat (1) tidak berlaku untuk:

a. surat yang menurut Undang-Undang harus dibuat dalam bentuk tertulis; dan

b. surat beserta dokumennya yang menurut Undang-undang harus dibuat dalam bentuk akta notaril atau akta yang dibuat oleh pejabat pembuat akta.

Berdasarkan Pasal tersebut maka putusan arbitrase termasuk yang harus dikecualikan, sehingga dengan demikian putusan arbitrase dalam bentuk elektronik tidak memenuhi persyaratan sebagai putusan arbitrase yang dinyatakan dalam Undang-undang No.30 Tahun 1999. Sehingga apabila diajukan permohonan eksekusi, maka pelaksanaannya akan ditolak. Dengan adanya ketentuan tersebut, maka penggunaan mekanisme

\footnotetext{
${ }^{63}$ Denden Imadudin Soleh, Kedudukan Putusan Arbitrase Online dalam Sistem Hukum Indonesia
} 
penyelesaian sengketa secara online menjadi tidak ada artinya, jika putusan arbitrase yang diperoleh para pihak secara online dianggap tidak sah secara hukum karena tidak memenuhi persyaratan sebagaimana ditentukan oleh Undang-undang No.30 Tahun 1999.

Arbitrase online sebagai salah satu bentuk penyelesaian sengketa bidang e commerce memang memberikan banyak keuntungan yaitu pendekatan yang fleksibel, efisiensi biaya,keahlian, kenyamanan, kecepatan, dan para pihak tidak perlu bertemu muka secara langsung. ${ }^{64}$ Untuk menerapkan arbitrase online di Indonesia memang dibutuhkan persiapan yang matang baik dari segi regulasi maupun infrastrukturnya karena dalam arbitrase online dibutuhkan seperangkat kelengkapan dan dukungan procedural serta akses internet yang memadai agar proses arbitrase online dapat berjalan lancer.

Untuk memenuhinya diperlukan persiapan yang terencana seperti website yang terintegrasi dengan aplikasi database untuk menampung permohonan yang masuk, daftar arbiter dan peraturan-peraturan yang diperlukan mengenai permohonan berarbitrase. ${ }^{65}$ Selain itu untuk menjamin kerahasiaan dan keontetikan data serta dokumen yang digunakan selama arbitrase online diperlukan aplikasi security yang memadai dan dilengkapi dengan teknologi enskripsi yang baik. Dan tentunya diperlukan juga penyediaan chatting room dan bulletin board yang berbasis real time audio visual streaming dan content management system khusus untuk para arbiter dalam menyelesaikan perkara. Hal itu demi kelancaran proses arbitrase online sehingga para pihak bisa mendapatkan kenyamanan dan kepastian hokum dalam menyelesaiakan sengketa e commerce yang mereka alami.

\footnotetext{
${ }^{64}$ Mochammad Basarah, Prosedur Alternatif Penyelesaian Sengketa Arbitrase Tradisional dan Modern (Online), Bandung: Genta Publishing, 2010, hlm. 148-151

${ }^{65}$ Bambang Sutiyoso, Penyelesaian Sengketa Bisnis Melalui Online Dispute Resolution dan Pemberlakuannya di Indonesia, Mimbar Hukum Volume 20, Nomor 2, Juni 2008, hlm. 235
} 


\section{PENUTUP}

\section{Kesimpulan}

Sistem perdagangan dengan memanfaatkan sarana internet tidak menutup kemungkinan timbul berbagai macam masalah dari transaksi online tersebut. Oleh karena itu dalam hal ini peranan hukum diperlukan guna menyelesaikan permasalahan- permasalahan tersebut sehingga ada jaminan dan kepastian hokum akan penyelesaian sengketa-sengketa tersebut. Jika dalam sengketa e commerce ini melibatkan para pihak yang tinggal di satu negara maka dalam penentuan hokum guna menyelesaikan sengketa dapat menggunakan hukum yang ada di Indonesia. Bila pelaku usahanya berada di luar yuridiksi hukum kita, maka persoalan pilihan hukum ini tergantung dari perjanjian antara pihak penjual dan pembeli (dengan cara menyantumkannya dalam salah satu klausul di perjanjian $e$ commerce). Choice of law ini merupakan bagian dari kebebasan berkontrak. Para pihak dapat pula menentukan di dalam perjanjian itu bahwa sengketa yang mungkin timbul di kelak kemudian hari diselesaikan oleh suatu badan arbitrase.

Dalam e commerce penyelesaian sengketa dapat dilakukan melalui pengadilan dapat pula dilakukan ADR ( Alternative Dispute Resolution). Penyelesaian sengketa melalui jalur litigasi ataupun non litigasi yang bersifat tradisional seperti arbitrase konvensional masih belum cukup untuk menjadi solusi penyelesaian sengketa e commerce yang pada dasarnya memiliki sifat virtual atau maya sehingga dibutuhkan suatu system yang efektif, efisien dan murah. Hadirnya arbitrase online merupakan terobosan dalama pilihan penyelesaian suatu sengketa. Arbitrase online pada dasarnya sama dengan arbitrase konvensioanl yang membedakan hanyalah media yang digunakan yaitu internet. Hal tersebut tentunya bisa menjadi alternative dalam memilih penyelesaian sengketa e commerce karena e commerce yang sifatnya lintas batas sehingga tidak menutup kemungkinan para pihak yang berada dalam wilayah hokum yang berbeda. Beberapa Negara maju telah menggunakan arbitrase online 
sebagai salah satu penyelesaian sengketa bisnis e commerce karena lebioh cepat efisisen dan efektif. Hanya saja dalam penerapannya arbitrase juga memiliki banyak kelemahan terutama dalam hal infrastruktur karenanya Indonesia saat ini belum menerapkannya. Diterapkannya arbitrase online di Indonesia maka Indonesia harus memiliki persiapan yang sangat matang baik dari segi regulasi maupun infrastrukstur jaringan internet yang memadai sehingga proses berabiotrase bisa berjalan lancer aman dan nyaman. 


\section{DAFTAR PUSTAKA}

\section{A. Literatur}

Ahmad. M. Ramli, Cyber Law dan Haki Dalam Sistem Hukum Indonesia, Refika Aditama,Bandung, 2004,

Dikdik M. Arief Mansur dan Elisatris Gultom, Cyber Law Aspek Hukum Teknologi Informasi, Refika Aditama, Bandung, 2005

M. Yahya Harahap, Arbitrase, Sinar Grafika, Jakarta, 2006.

Mochamad Basarah, Prosedur Alternatif Penyelesaian Sengketa Arbitrase Tradisional dan Modern (Online), Genta Publishing, Bandung, 2010

Peter Mahmud Marzuki ,penelitian Hukum, Prenada Media Group, Jakarta, 2005

R. subekti dan R. Tjitrosudibio, "Kitab Undang-Undang Hukum Perdata", Pradnya Paramita, Jakarta, 1996

Salim H.S, Hukum Kontrak (Teori dan Teknik Penyusunan Kontrak), Sinar Grafika, Jakarta 2003

Subekti, Hukum Perjanjian, Intermasa, Jakarta,1985

\section{B. Perundang-undangan}

Undang-Undang Nomor 30 Tahun 1999 tentang Arbitrase dan Penyelesaian Masalah

Undang-Undang Nomor 11 Tahun 2008 tentang Informasi dan Transaksi Elektronik

\section{Internet}

Faizin Sulistio " Tinjauan Yuridis arbitrase Online sebagai alternatif Penyelesaian sengketa E-Commerce” <http://ijink97.wordpress.com/2008/08/14/arbitrase-online/>

Denden Imadudin Soleh "Kedudukan Putusan Arbitrase Online Dalam Sistem Hukum Indonesia“ $<$ http://dendenimadudin.blogspot.com/2010/08/kedudukan-putusan-arbitraseonline.html> 
Bambang Sutiyoso, Penyelesaian Sengketa Bisnis Melalui Online Dispute Resolution dan Pemberlakuannya di Indonesia, Mimbar Hukum Volume 20, Nomor 2, Juni 2008.

Sekilas Kejahatan E-Commerce Di Indonesia « Makalah, Berita, Paparan dan Diskusi Masalah Hukum 'Law Education'.htm

http://id.wikipedia.org/wiki/Perdagangan elektronik http://hukumonline.com/klinik/detail/cl1467 http://hukumonline.com/klinik/detail/c15517 http://hukumonline.com/klinik/detail/cl5397 